\title{
Comparison of the Methods for LS Factor Calculation when Evaluating the Erosion Risk in a Small Agricultural Area Using the USLE Tool
}

\author{
Petr Karásek ${ }^{1 *}$, Michal Pochop'1, Jana Konečná', Jana Podhrázská' \\ ${ }^{1}$ Research Institute for Soil and Water Conservation, v.v.i., Department of Land Consolidations and Land Use \\ Planning, Lidická 25/27, 60200 Brno, Czech Republic \\ * Corresponding author's e-mail: karasek.petr@vumop.cz
}

\begin{abstract}
In the projects of anti-erosion protection in the Czech Republic, USLE was used as a standard tool for evaluating the risk of water erosion. The precision of the resulting USLE values is defined by the quality of input data and algorithms used. Two methods for LS factor calculation are recommended for use in the planning practice in the Czech Republic: the computing method based on the USLE 2D software and the other computing methods. Various methods can assess the LS factor; however, their results differ. On the example of the Starovice - Hustopeče study area (Czech Republic), strongly threatened by erosion, this report aimed to show the differences brought using these differing methods of LS factor assessment, all in two variants before and after application of antierosion measures (retention grass belts, grassed thalweg). Changes in the calculation of the LS factor were directly reflected in the calculation of the long-term average soil loss by water erosion.
\end{abstract}

Keywords: water erosion; land use; GIS; LS factor; USLE; anti-erosion measures

\section{INTRODUCTION}

Protecting agricultural land from erosion (water and wind) is a major issue worldwide. It can be assumed that the importance of agricultural land protection will continue to grow in the future. Soil is an irreplaceable natural resource. Although soil erosion is a natural process, it has been significantly accelerated through intensive agricultural activity. The loss of agricultural land by erosion leads to irreparable damage to the landscape. As a result of increasing weather extremes, more frequent extreme climatic events occur, including periods of drought, heavy rains, and flash floods. All these phenomena result in an increased risk of erosion and flash floods worldwide [Walling 2009; Konečná et al. 2019; Thomas 2006; Hartvigsen 2014]. The Czech Republic is no exception. Intensive agricultural activity in the second half of the 20th century resulted in a significant increase in erosion. The effort to maximize the efficiency of agricultural production led to the elimination of most natural vegetation barriers in the landscape (spinneys, balks). Extensive arable land blocks of hundreds of hectares in size with monocultures of marketable crops (maize, rape, wheat) were formed. Unfortunately, such large soil blocks were also created on sloping localities. As a result, more than $50 \%$ of farmland in the Czech Republic (CR) is currently threatened by soil erosion [Dostál et al. 2006; Podhrázská et al. 2015; Podhrázská et al. 2019]. At present, the maximum soil loss in CR is estimated to be approximately 21 million tons of arable land per year, which may be expressed as an economic loss of CZK 4.3 billion per year [Podhrázská et al. 2015]. The solution to the erosion problems is the design and implementation of appropriate anti-erosion measures. The implementation of these measures is expensive and takes many years. For optimal and effective design of suitable anti-erosion measures in specific localities, it is necessary to know the current state of erosion risk (i.e. the initial state). The current erosion and factors 
influencing erosion processes in specific localities can be determined using the methods based on modeling of erosion risk. Many authors and scientific teams around the world are involved in modeling the erosion processes using different methods [Onyando et al. 2005; Krasa et al. 2005; Bhattarai and Dutta 2007; Beskow et al. 2009; Kapička et al. 2017, Kumar and Kushwaha 2013].

One of the most widely used methods is the empirical equation "Universal Soil Loss Equation" (USLE) [Wischmeier, Smith, 1978]. This method (equation) is also used in the Czech Republic, mainly due to its simplicity. Interpretation of the universal equation factors under the conditions of CR was done by several authors [Zdražil 1965; Holý 1978, 1994; Pasák 1984; Toman 2000; Janeček et al. 2012; Karásek et al. 2019]. Assessment of the erosion risk using USLE leads to the determination of the long-term average loss of soil by water erosion in the study area. The quality of the resulting calculation is directly dependent on the accuracy of the input values (USLE factors) R, K, C, P, and the methods used to calculate the LS factor [Janků et al. 2016; Žížala et al. 2017; Konečná et al. 2019]. The LS factor can be calculated by using several methods within this equation (and its application in geographic information systems - GIS).

The USLE 2D software was developed by Van Oost and Govers [2000]. The software is used for the calculation of LS factor in combination with GIS. The LS factor is created from the digital model of the terrain (DMT) and the layer of land parcels distributing the area into partial surfaces. The calculation relies on the presumption that the borders between partial surfaces act as barriers interrupting global surface runoff. This diminishes the length of the runoff pathway and the value of the L factor [Kozlovsky-Dufková and Toman 2014]. According to the computing algorithm, the LS factor is calculated separately for each grid element [Efe et al. 2000]. The program performs runoff tracing based on the vector decomposition (Flux Decomposition) [Desmet and Govers 1996]. The algorithm for LS factor computation is defined by the user - according to Wischmeir and Smith, McCool, Govers and Nearing [Van Oost and Govers 2000]. The second method used to determine the LS factor according to Mitášová et al. [1996] is modified for broken terrain. In order to integrate the effect of the concentrated surface runoff, the length of the runoff pathway (L factor) was replaced by the 'contributing surface' above the computed grid cell comprising the runoff entering the said cell. The LS factor computed in this way better chraracterizes for the effect of concentrated runoff on the increasing erosion. The entire method can be applied in the GIS environment [Mitášová and Mitáš 1999].

However, different methods of calculating the LS factor give varying results. The article focuses on the comparison of erosion risk (in the Starovice - Hustopeče model area) using 2 different methods of calculating the LS factor (within the USLE equation). These include the USLE 2D software and a method of calculating the LS factor according to the equation Mitášová et al. [1996]. This difference also leads to different results of the erosion risk calculation.

\section{METHODOLOGY AND DATA}

\section{Starovice - Hustopeče u Brna Model locality}

The Starovice-Hustopeče model locality was chosen to demonstrate the calculation of the LS factor values (by using two different methods) and the calculation of erosion risk using the USLE method. The study area is in the Czech Republic, South Moravia region (see Fig. 1). This is an agricultural area (production of field crops), which is highly productive and fertile. The soils are mostly chernozems. The area of the locality is 223.5 ha. The area has long been strongly threatened by water erosion. The main reason for the strong erosion risk is the high average slope (reaching 7\%) and the long slope of the locality (the length of the slope along $1700 \mathrm{~m}$ ) (see Fig. 2). Such a long slope without interrupting elements (boundaries, ditches) is the main cause of strong erosion and surface runoff of water from torrential rainfall. In the past, surface runoff and strong erosion caused local floods in the town of Hustopeče.

The way to protect this site from the effects of erosion and flash floods is to interrupt the slope with suitable anti-erosion elements. In the years 2000-2003, land consolidation was processed in the study area. The main goal of land consolidation was to design anti-erosion and flood control measures. A dry polder, grassed thalweg, 5 retention grass belts were designed for implementation in the area. These elements of anti-erosion and flood protection were gradually implemented in the years 2009-2017. The area of all realized 


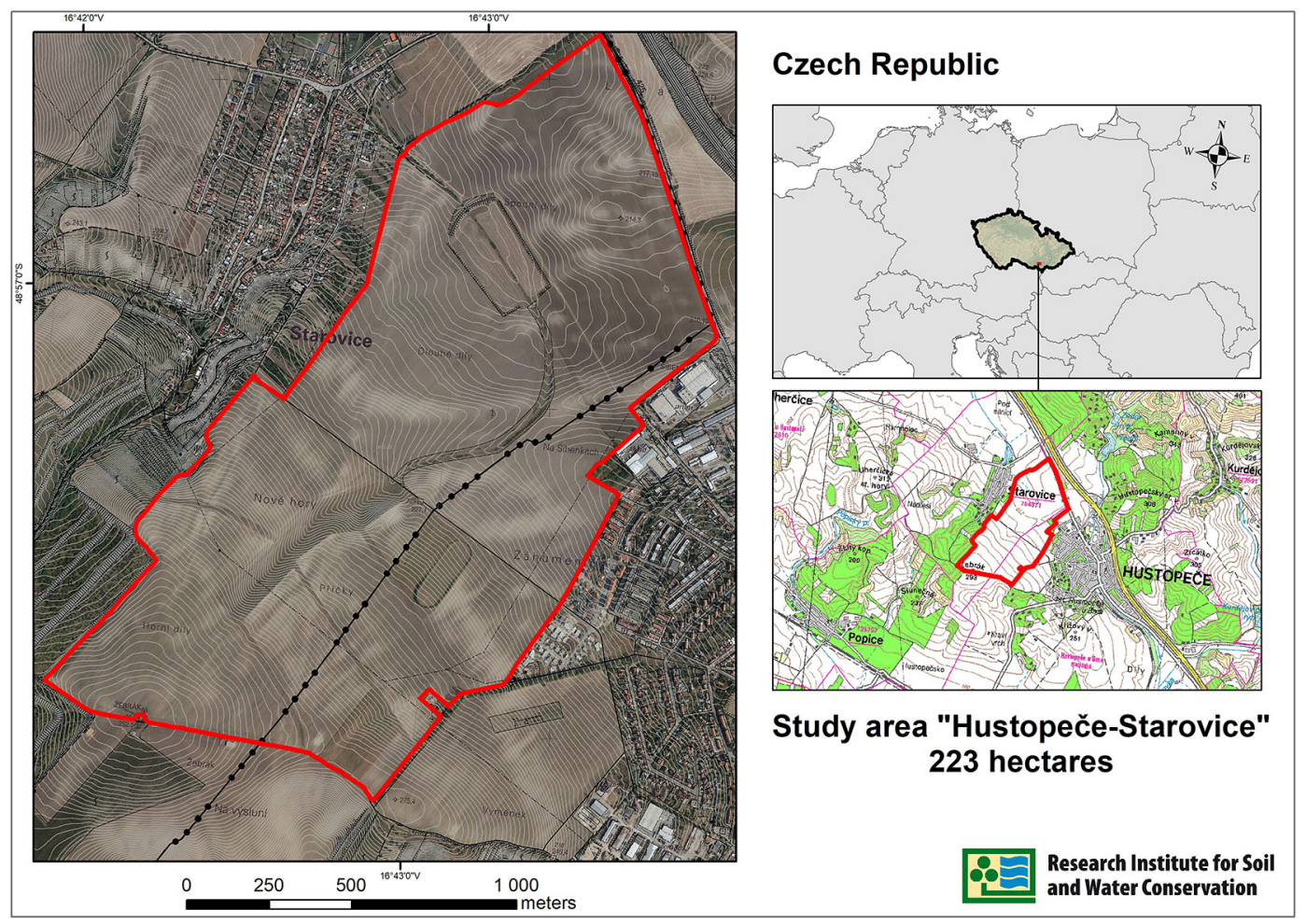

Fig. 1. Location of the Starovice - Hustopeče study area (South Moravia Region, Czech Republic)

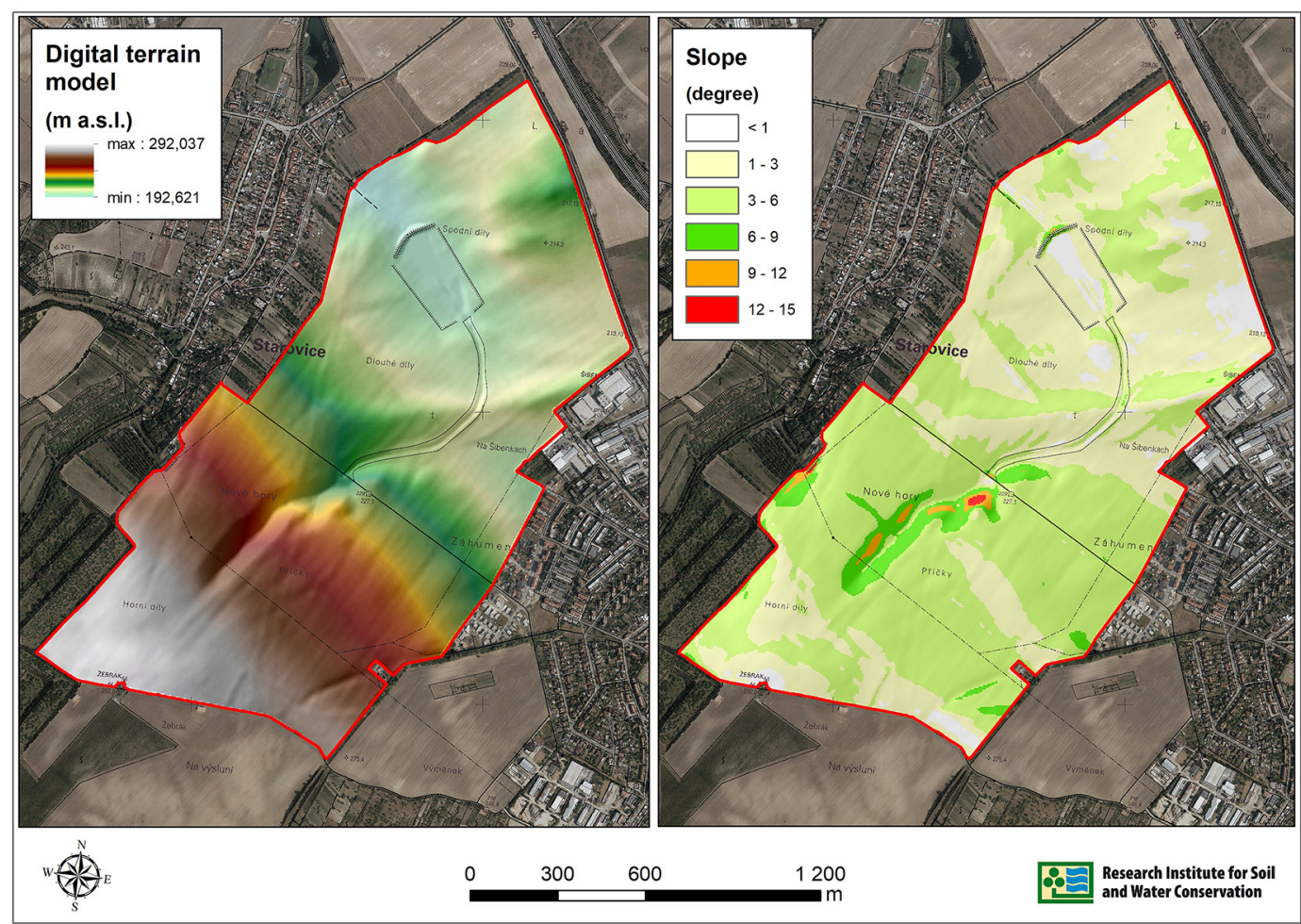

Fig. 2. Morphological characteristic of the Starovice - Hustopeče study area (South Moravia Region, Czech Republic)

elements exceeded 16 ha. These anti-erosion elements interrupt the length of the slope (the LS factor). For this reason, it is possible to demonstrate changes in the LS factor in variant states (different methods) and a different state of the land use (before the implementation of antierosion and anti-flood measures and after their implementation). 


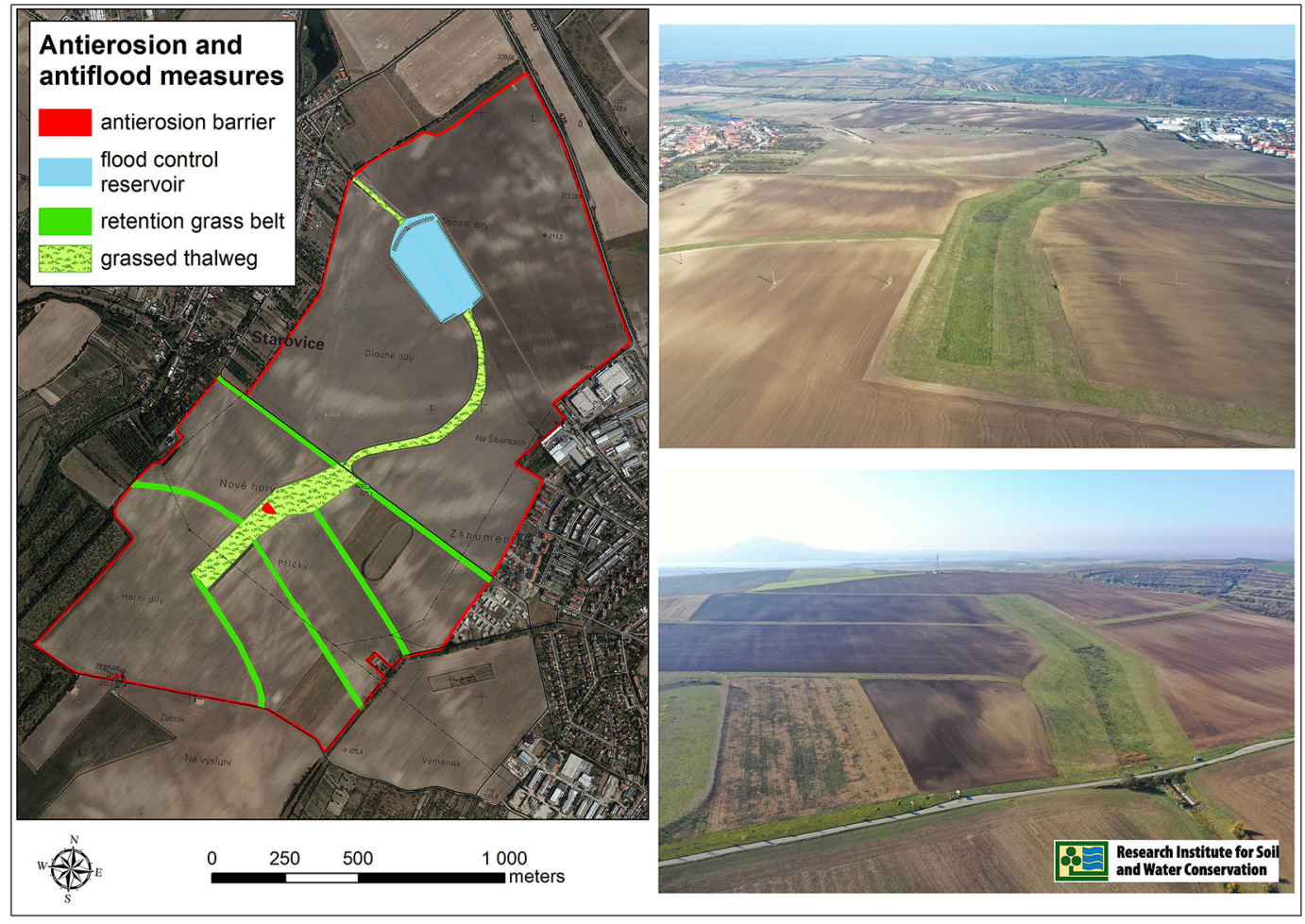

Fig. 3. Anti-erosion and anti-flood measures applied to the Starovice Hustopeče study area (South Moravia Region, Czech Republic)

\section{Calculation of long-term average soil loss by water erosion}

The USLE (Universal Soil Loss Equation) is a globally used method of calculating and evaluating the long-term average soil loss by water erosion. In the Czech Republic, this method has been used since the early 1990s. The quality of the calculation of this model depends on the input data, i.e. their accuracy. A number of workplaces and authors have long been involved in the implementation of this equation for the Czech Republic. The currently used methodology of USLE calculation in the Czech Republic comes from the author's team of Janeček et al. [2012], where input parameters of these model listed:

- $\mathrm{R}$ factor, $\mathrm{R}=40 \mathrm{MJ} \cdot \mathrm{ha}^{-1} \cdot \mathrm{cm} \cdot \mathrm{h}^{-1}$,

- $\mathrm{K}$ factor - values (constants) for individual soils determined according to the research of soil characteristics in the Czech Republic [Vopravil et al. 2011],

- $\mathrm{C}$ factor - determined on the basis of the research into the structure of cultivated crops in individual climatic regions of the Czech Republic [Kaldec and Toman 2002],

- Factor $\mathrm{P}=1$,

- LS factor - used two variant calculation methods.
Parameters $L$ (the slope length factor) and $S$ (the slope steepness factor) are commonly used as topographic factors $(L S)$. The total erosion loss per unit increases along with the slope length/ steepness, as a result of progressive accumulation, velocity and erosivity of runoff [Wischmeier and Smith 1978]. The LS factor was processed based on the $4^{\text {th }}$ generation digital terrain model (DTM) at the $5 \times 5 \mathrm{~m} /$ pixel resolution (used in the Czech Republic). The LS factor was calculated using two methods recommended for use in the Czech Republic. The data layer was prepared from the grid layer of the digital terrain model (DTM) and the grid layer of land blocks in the spatial resolution of $5 \times 5 \mathrm{~m} /$ pixel.

The calculation of the LS factor in the Hustopeče-Starovice study area was done in USLE 2D software (Routing Algorithm - Flux Decomposition, LS Algorithm - McCool) [Van Oost and Govers 2004]. LS factor was calculated by the equation according to Mitasova et al. [1996]. The first step consists in using hydrologic tools to create the layer of flow direction with smoothed DMT, which defines the qualitative (direction) and quantitative (amount) runoff features. In addition, to create the grid, flow accumulation is determined based on gradual recording of runoff accumulation from the surrounding cells to 
the computed cell (which itself is not included). The high accumulation values in the cells represent the surfaces of runoff concentration. This is followed by creation of the slope layer from DMT. These two layers give rise to the LS factor using the Raster Calculator function [KozlovkyDufková and Toman 2014[. The following equation was used to calculate the $L S$ values in USLE:

$$
L S=(A / 22.13)^{1.6} \mathrm{x}(\sin B / 0.0896)^{1.3}
$$

where: $A$ is the upslope contribution factor (flow accumulation),

$B$ is the slope steepness in degrees.

\section{RESULTS}

\section{Comparison of the resulting values of LS factor}

The evaluation of the mean long-term soil loss by water erosion was performed in four variants (Table 1). When using differing methods of LS factor assessment, differing results were found in the LS factor values during the evaluation of the area state both before application of the anti-erosion measures (Fig. 4) and afterwards (Fig. 5). In both cases, the LS factor grids differed not only visually, but also after evaluation by zonal statistics.

The value of LS factor according to the variants:

- $\quad$ variant $1 \mathrm{~A}: \varnothing \mathrm{LS}$ factor $=2.78$

- variant $2 \mathrm{~A}: \varnothing \mathrm{LS}$ factor $=2.13$

- variant $1 \mathrm{~B}: \varnothing \mathrm{LS}$ factor $=1.68$

- variant 2B: Ø LS factor $=1.40$
The resulting mean LS factor value of variant $1 \mathrm{~A}$ exceeded that of variant $2 \mathrm{~A}$ by $23 \%$. Thus, identical input layers bring significantly differing results using differing methods of the LS factor assessment. The same situation was found in the case of LS factor assessment after the application of anti-erosion measures. In this case, variant $1 \mathrm{~B}$ exceeded variant $2 \mathrm{~B}$ by $16 \%$. Under both evaluated conditions of the model area, the LS factor values were higher (by 16-23\%) when using the equations and algorithms implemented in the USLE 2D software. This is also confirmed by the histogram of the rate of individual LS factor value intervals (Fig. 6).

The frequency histograms in both assessed variants $1 \mathrm{~A}$ vs. $2 \mathrm{~A}$ and $1 \mathrm{~B}$ vs. $2 \mathrm{~B}$ differ from each other. The interval (frequency of LS factor values) $0-1$ covers a significantly larger surface of the study area when computing the LS factor by the equation according to Mitášová et al. [1996] (ca. 101 ha) compared to the computation using USLE 2D (58 ha). In all other intervals of histogram values, however, the situation is opposite (Fig. 6).

These differences can also be identified in the visual comparison of the resulting LS factor grids. The LS factor grid processed by the equation according to Mitášová is characterized by a line structure of increasing the LS factor values (in the direction of water flow downstream the slope), with characteristic sharp transitions between high and low values. This is the consequence of using this method of LS factor establishment, where one equation input is represented by the runoff concentration grid (flow accumulation). This input is characteristic by the line structure of grid cells, where the growing values (grid cells) flow down in the direction of surface runoff concentration downstream

Table 1. Factors of the USLE equation, values and data sources used for the model applied

\begin{tabular}{|c|c|c|c|c|c|c|c|}
\hline \multirow{4}{*}{ Var. } & \multicolumn{5}{|c|}{ USLE factor } & \multirow{2}{*}{\multicolumn{2}{|c|}{ Antierosion measures }} \\
\hline & LS & $\mathrm{R}$ & $\mathrm{K}$ & C & $\mathrm{P}$ & & \\
\hline & \multirow[t]{2}{*}{$\begin{array}{c}\text { Topographic factor (slope length } \\
\text { and steepness) [-] }\end{array}$} & $\begin{array}{l}\text { Rainfall erosivity } \\
\text { factor } \\
{\left[\mathrm{Mj} \cdot \mathrm{ha}^{-1} \cdot \mathrm{cm} \cdot \mathrm{h}^{-1}\right]}\end{array}$ & $\begin{array}{l}\text { Soil } \\
\text { erodibility } \\
\text { factor }[-]\end{array}$ & $\begin{array}{l}\text { Cover and } \\
\text { management } \\
\text { factor }[-]\end{array}$ & $\begin{array}{l}\text { Support } \\
\text { practice } \\
\text { factor }[-]\end{array}$ & \multirow{2}{*}{\multicolumn{2}{|c|}{$\begin{array}{l}\text { Grassed thalweg, } \\
\text { stabilization of thalwegs } \\
\text { by erosion barrier, } \\
\text { retention grass belts, } \\
\text { retention reservoir }\end{array}$}} \\
\hline & & \multicolumn{4}{|c|}{ [Janeček et al. 2012] } & & \\
\hline $1 \mathrm{~A}$ & Computation based on USLE & 40 & \multirow{4}{*}{$0.16-0.49$} & \multirow{4}{*}{$\begin{array}{l}0.005 \text { permanent } \\
\text { grassland } 0.307 \\
\text { arable land }\end{array}$} & \multirow{4}{*}{1} & no & before 2009 \\
\hline $1 \mathrm{~B}$ & $\begin{array}{l}\text { Van Oost and Govers 2004] } \\
\text { Van }\end{array}$ & 40 & & & & no & before 2009 \\
\hline $2 \mathrm{~A}$ & \multirow{2}{*}{$\begin{array}{l}\text { Computation based on equation } \\
\text { [Mitášová et al. 1996] }\end{array}$} & 40 & & & & yes & present day \\
\hline $2 \mathrm{~B}$ & & 40 & & & & yes & present day \\
\hline
\end{tabular}




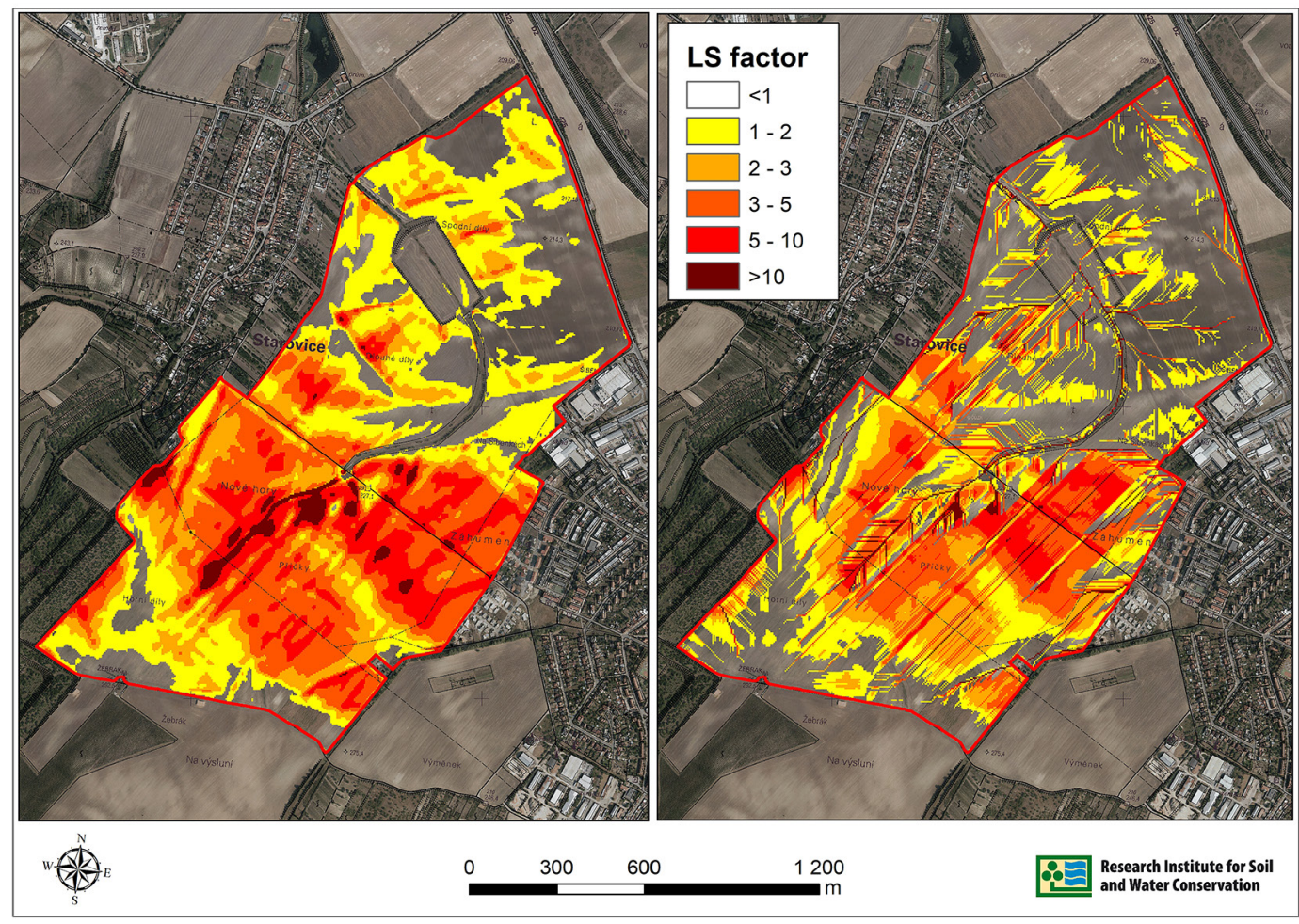

Fig. 4. Assessment of LS factor by using the USLE 2D method (left) and the equation according to Mitášová (1996) (right); (state before application of anti-erosion measures)

the slope. It means that in between cells with high LS factor value, there are many cells with minimum or zero value of the LS factor. The equation is therefore suitable for the localities with high LS values. However, when processing the zonal statistics and determining the weighted

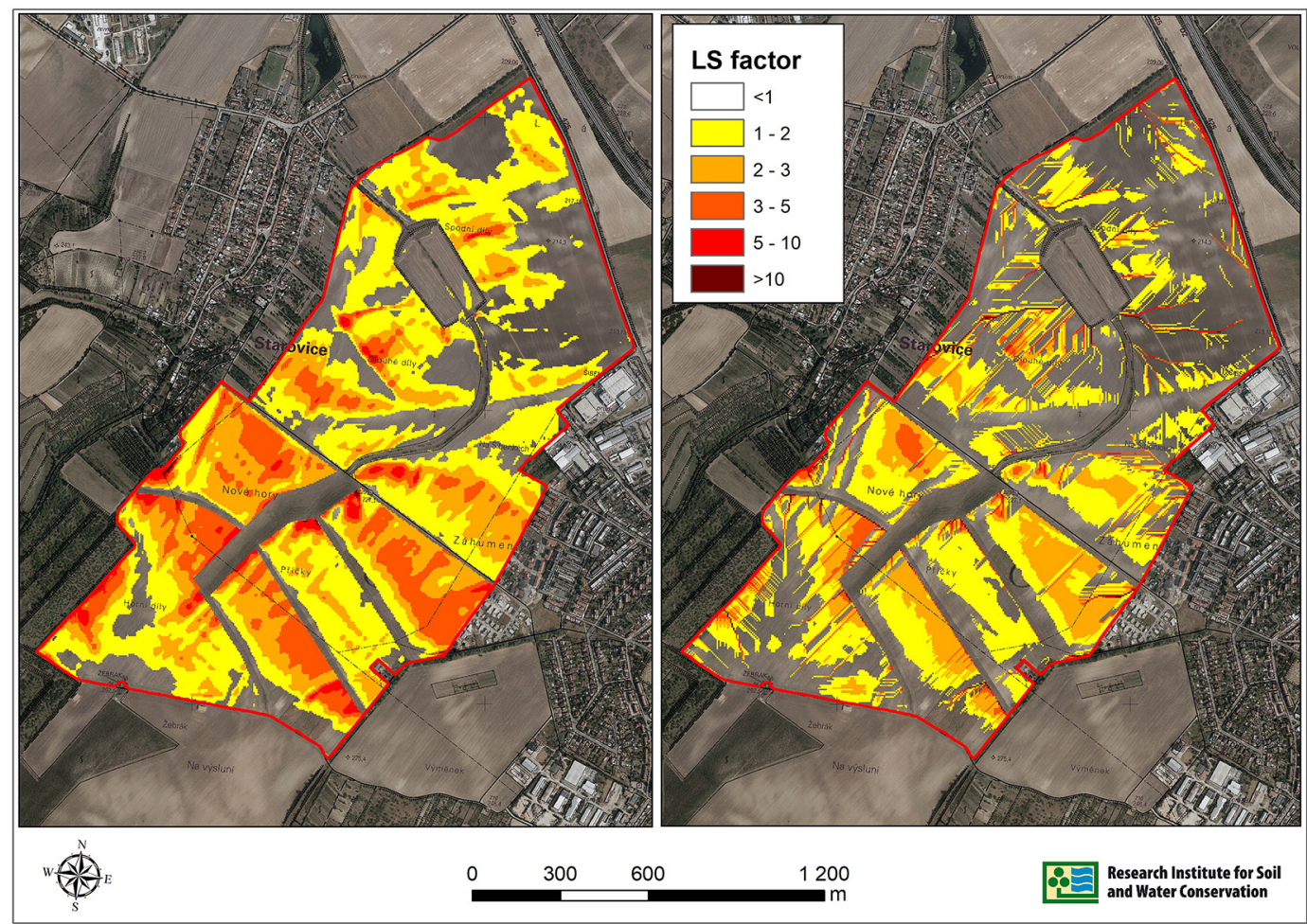

Fig. 5. Assessment of LS factor by using the USLE 2D method (left) and the equation according to Mitášová et al. [1996] (right); (current state after application of anti-erosion measures) 


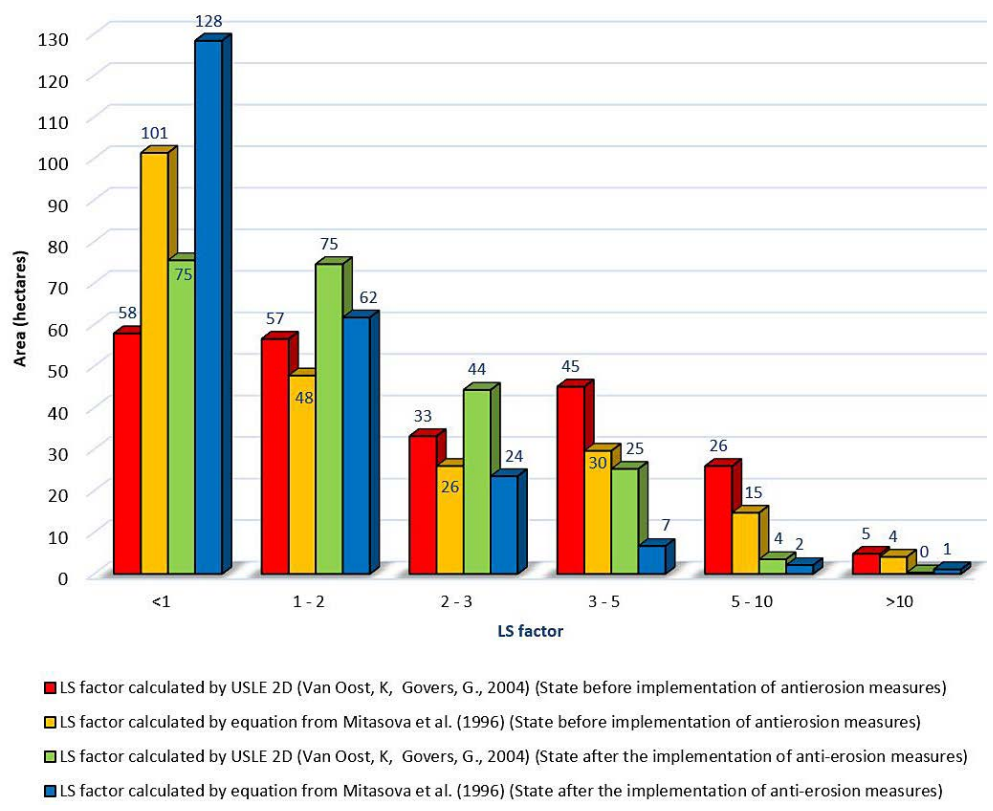

Fig. 6. Comparative histograms of LS factor values determined by using the USLE 2D method [Van Oost and Govers 2004) and equation according to Mitášová et al. [1996] for two periods, before and after application of anti-erosion measures, in study area Starovice - Hustopeče

mean (mean value), this equation leads to bias (due to the fact that the LS factor is assessed in lines and not in surface). In contrast, the method of LS factor computation using the USLE 2D software creates continuous surfaces of growing LS factor values. It does not create sharp (line) transitions between the LS values.

\section{Comparison of the resulting values of mean long-term soil loss by water erosion}

The differing approaches to LS factor determination were also reflected in the results of evaluation of the mean long-term soil loss by the USLE method. The mean value of long-term soil loss by water erosion ( $\mathrm{G} t / \mathrm{ha} /$ year) (according to individual LS factor variants and area states regarding the anti-erosion protection):

- variant $1 \mathrm{~A}: \varnothing \mathrm{G}=13.7[\mathrm{t} / \mathrm{ha} /$ year $]$

- variant $2 \mathrm{~A}: \varnothing \mathrm{G}=9.8[\mathrm{t} / \mathrm{ha} /$ year $]$

- variant $1 \mathrm{~B}: \varnothing \mathrm{G}=3.2[\mathrm{t} / \mathrm{ha} / \mathrm{year}]$

- variant $2 \mathrm{~B}: \varnothing \mathrm{G}=2.3[\mathrm{t} / \mathrm{ha} /$ year]

The results show a significant reduction of the mean long-term soil loss by water erosion. This reduction is a result of application of a complex system of anti-erosion measures. However, there are also apparent differences in the values of erosion risk brought using differing methods of processing the input layer of
LS factor; these differences are not negligible. When evaluating the state before the application of anti-erosion measures, the mean soil loss by water erosion fluctuates around $28 \%$. After the application of the anti-erosion measures, the values fluctuate around $29 \%$. The differences brought by the different methods are therefore significant, even when evaluating the same state of the study area.

The binding limit for the mean long-term (permissible) soil loss in the Czech Republic is $4 \mathrm{t} / \mathrm{ha} /$ year. This limit is compulsory for the planners of anti-erosion protection. The project of anti-erosion measures must therefore be as effective as to reduce the mean long-term soil loss by water erosion under this value. This limit (value) is calculated as a mean value of the grid of mean long-term soil loss by water erosion $(G)$ (assessed by USLE) related to the 'erosion-evaluated area.' The erosion-evaluated area is the territory without interruption of the erosion effects by a technical element (ditch, water flow, buildings, etc.). The results of this report clearly show that the determined values of the mean long-term soil loss can be significantly impacted not only by the utilized values of input factors, but also by the method used for LS factor determination. The differences in the order of tens of percent may be essential for the planners of anti-erosion protection. 


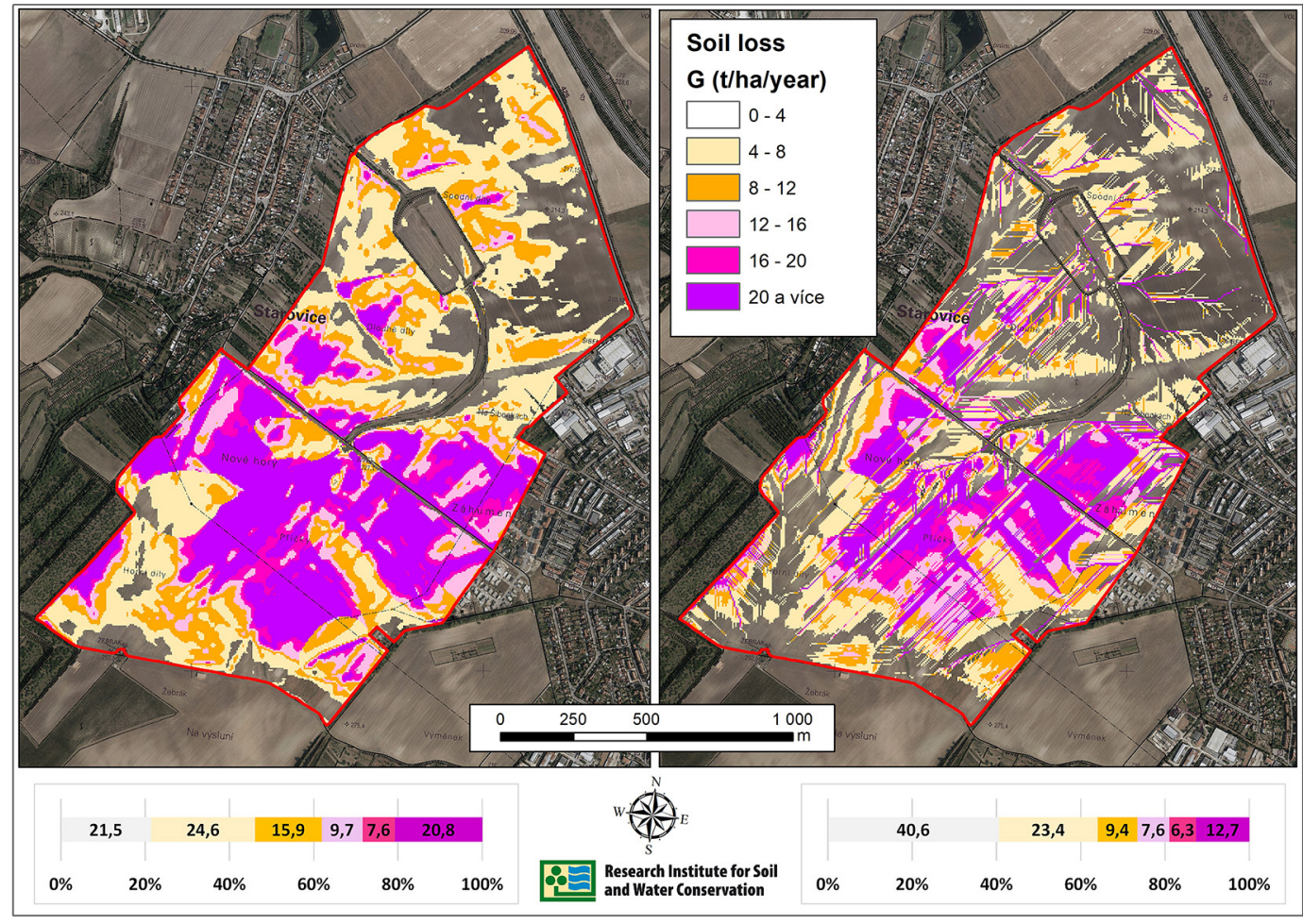

Fig. 7. Evaluation of water erosion (left, using the LS factor according to USLE 2D; right, using the LS factor according to Mitášová et al. [1996]); (state before application of anti-erosion measures)

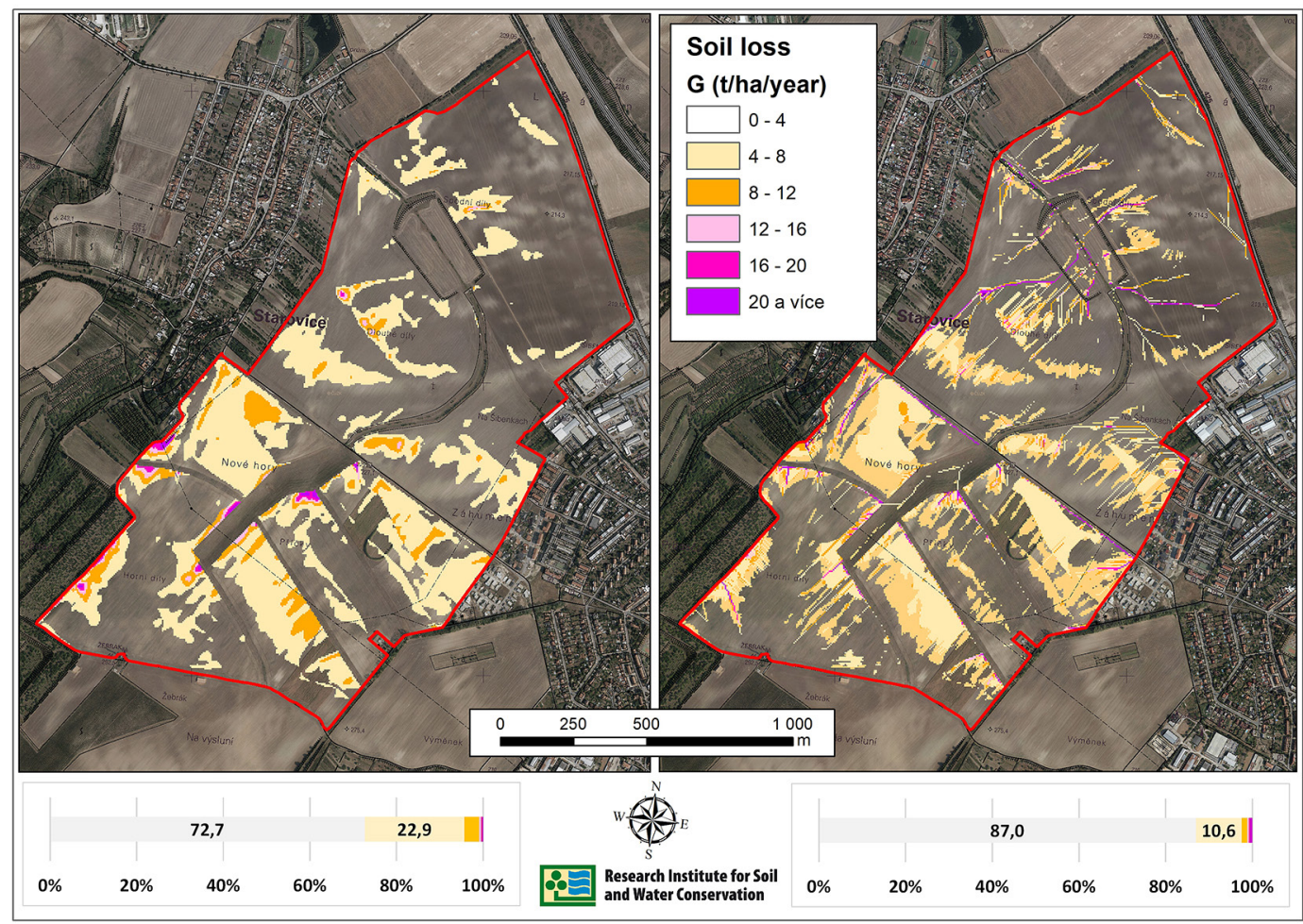

Fig. 8. Evaluation of water erosion (left, using the LS factor according to USLE 2D; right, using the LS factor according to Mitášová et al. [1996]); (current state after application of anti-erosion measures) 
Table 2. Evaluation of water erosion by the USLE tool using differing methods of LS factor assessment for two states, before and after application of anti-erosion measures, in the Starovice - Hustopeče locality

\begin{tabular}{|c|c|c|c|c|c|c|c|c|}
\hline \multirow{3}{*}{$\begin{array}{l}\text { Soil loss G [t/ } \\
\text { ha/year] }\end{array}$} & \multicolumn{4}{|c|}{$\begin{array}{l}\text { State before application of anti-erosion measures } \\
\text { in } 2007\end{array}$} & \multicolumn{4}{|c|}{$\begin{array}{l}\text { State after application of anti-erosion measures } \\
\text { in } 2020\end{array}$} \\
\hline & \multicolumn{2}{|c|}{$\begin{array}{l}\text { LS factor calculated } \\
\text { by USLE 2D [Van Oost } \\
\text { and Govers 2004] }\end{array}$} & \multicolumn{2}{|c|}{$\begin{array}{l}\text { LS factor calculated } \\
\text { by equation from } \\
\text { Mitasova et al. [1996] }\end{array}$} & \multicolumn{2}{|c|}{$\begin{array}{l}\text { LS factor calculated } \\
\text { by USLE 2D [Van Oost } \\
\text { and Govers 2004) }\end{array}$} & \multicolumn{2}{|c|}{$\begin{array}{c}\text { LS factor calculated } \\
\text { by equation from } \\
\text { Mitasova et al. [1996[ }\end{array}$} \\
\hline & [ha] & [\%] & [ha] & [\%] & [ha] & [\%] & [ha] & [\%] \\
\hline $0-4$ & 47.9 & 21.5 & 90.7 & 40.6 & 162.5 & 72.7 & 194.4 & 87.0 \\
\hline $4-8$ & 55.0 & 24.6 & 52.3 & 23.4 & 51.2 & 22.9 & 23.6 & 10.6 \\
\hline $8-12$ & 35.4 & 15.9 & 21.0 & 9.4 & 7.6 & 3.4 & 2.7 & 1.2 \\
\hline $12-16$ & 21.6 & 9.7 & 17.0 & 7.6 & 1.1 & 0.5 & 0.9 & 0.4 \\
\hline $16-20$ & 17.1 & 7.6 & 14.1 & 6.3 & 0.5 & 0.2 & 0.5 & 0.2 \\
\hline$>20$ & 46.5 & 20.8 & 28.3 & 12.7 & 0.5 & 0.2 & 1.3 & 0.6 \\
\hline total & 223.5 & 100.0 & 223.5 & 100.0 & 223.4 & 100.0 & 223.4 & 100.0 \\
\hline
\end{tabular}

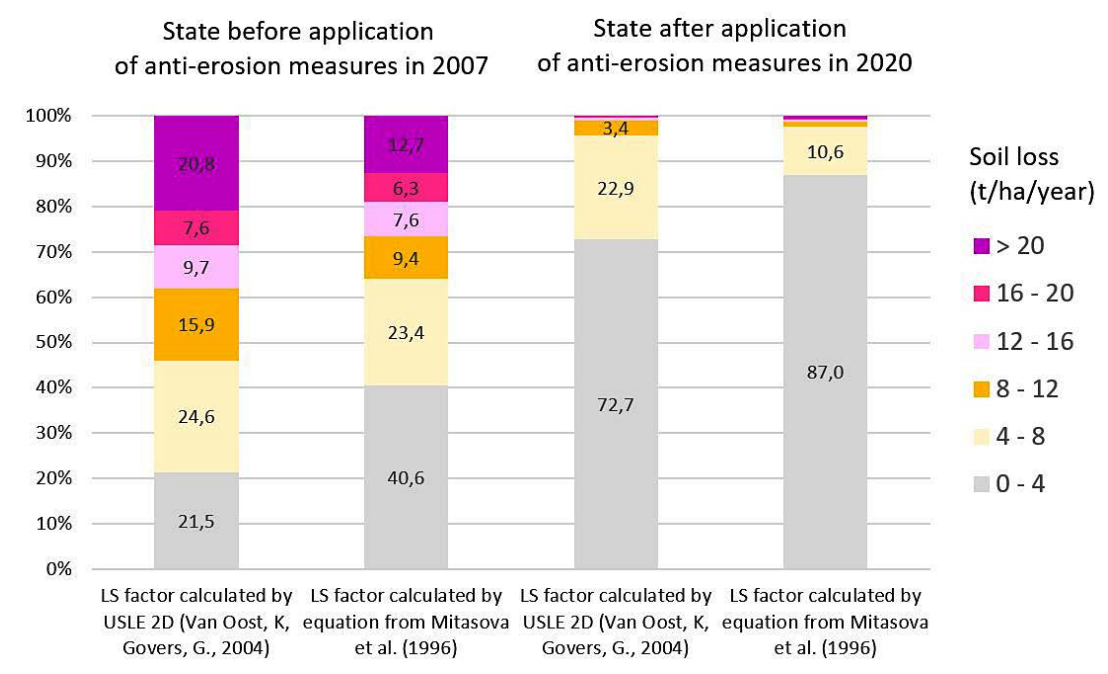

Fig. 9. Comparative histograms of mean long-term soil loss determined by the two methods of LS factor computation (USLE 2D [Van Oost and Govers 2004] and equation according to Mitášová et al. [1996]) for two periods, before and after application of anti-erosion measures, in the Starovice - Hustopeče study area

\section{CONCLUSIONS}

This report was not intended to answer the question which of the two utilized methods of LS factor determination best corresponds to the real state and actual natural processes. Without further measurement and validation, which of these methods of LS factor assessment better describes the state of erosion risk cannot be determined unambiguously. The aim of this report is to show that the choice itself of the method of LS factor determination is essential for the overall result of evaluation of the mean long-term soil loss by the USLE tool. In the Czech Republic, both the methods of LS factor assessment mentioned above are allowed for use. When interpreting their results, one should therefore consider the facts described in this report. The established limit for long-term permissible soil loss by water erosion of $4 \mathrm{t} / \mathrm{ha} /$ year (for the Czech Republic) is compulsory for the planners of anti-erosion protection. By using variant methods of LS factor determination, however, this permissible soil loss can be achieved by both an easier and a more difficult way. The differing results of the two methods of the LS factor determination were also pointed out by other previous studies with similar results as our research

\section{Acknowledgements}

The research was financially supported by research projects TJ04000342 and Ministry of Agriculture of the Czech Republic, Project No. RO2021. 


\section{REFERENCES}

1. Bhattarai, R., Dutta, D. 2007. Estimation of soil erosion and sediment yield using GIS at catchment scale. Water Resources Management, 21: 1635-1647.

2. Beskow, S., De Mello, C.R., Darrell, N.L., Curi, N., Viola, M.R., Avanzi, J.C. 2009. Soil erosion prediction in the Grande River Basin, Brazil using distributed modelling. Catena, 79 (1), 49-59.

3. Desmet, P.J.J.; Govers, G. A. 1996. GIS procedure for automatically calculating the USLE LS factor on topographically complex landscape units. Soil Water Conservation, 51, 427-433.

4. Dostál T., Janeček M., Kliment Z., Krása J., Langhammer J., Váška J., Vrána K. 2006. In Boardman J., Poesen J. (eds.) Soil erosion in Europe. Chichester: John Wiley \& Sons Ltd., 107-116.

5. Efe, R., Ekinci, D., Curebel, I., 2000 Erosion analysis of Sahin watershed (NW of Turkey) using GIS based on RUSLE (3d) method; J. Appl. Sci. 8(1), 49-58.

6. Hartvigsen, M. 2014. Land mobility in Central and Eastern Europe land consolidation context. Nordic Journal of Surveying and Real Estate Research, 10(1), 23-46.

7. Holý, M. 1994. Erosion and the Environment. Czech Technical Institute, Prague. (in Czech).

8. Holý, M. 1978. Anti-erosive Protection. National Publishing House for Technical Literature, Prague. (in Czech).

9. Janeček, M. et al. 2012. Protection of agricultural land against erosion. Methodology. Prague. (in Czech).

10. Kadlec, M., Toman, F. 2002. Correlation between the anti-erosive factor effectiveness of vegetation cover $\mathrm{C}$ and the climatic region. In: Bioclimate Environment - Management.

11. Kapička, J., Novotný, I., Žížala, D. 2017. Monitoring of agricultural land - final report. Prague, VÚMOP. (in Czech).

12. Karásek, P., Kučera, J., Szturc, J., Podhrázská, J., Konečná, J. 2019. Causes of water erosion and benefits of anti-erosion measures in model locality Starovice - Hustopeče (South Moravia Region, Czech Republic). Journal of Ecological Engineering, 20(2), 95-105.

13. Konečná, J., Pražan, J. et. al. 2014. Assessment of economic aspects of erosion control of agricultural land. Certified methodology. Research Institute for Soil and Water Conservation, v.v.i. (in Czech).

14. Konečná J., Karásek P., Beitlerová H., Fučík P., Kapička J., Podhrázská J., Kvítek T. 2020: Using WaTEM/SEDEM and HEC-HMS models for the simulation of episodic hydrological and erosion events in a small agricultural catchment. Soil \& Water Res., 15, 18-29.

15. Krasa, J., Dostal, T., Van Rompaey, A., Vaska, J., Vrana, K. 2005. Reservoirs' siltation measurements and sediment transport assessment in the Czech Republic, the Vrchlice catchment study. Catena, 64, 348-362.
16. Kozlovsky Dufková, J.K., Toman, F. 2014. Calculation of soil washing using chosen empirical models of water erosion. In Rožnovský, J., Litschmann, T., Středa, T., Středová, H. Extremes in Water Circulation in the Landscape, in Czech. Prague: Czech Hydrometeorological Institute, 2014.

17. Kumar, S., Kushwaha, S.P.S. 2013. Modelling soil erosion risk based on RUSLE-3D using GIS in a Shivalik sub-watershed. Journal of Earth Science, 122(2), 389-398.

18. Mitasova, H., Hofierka J., Zlocha, M., Iverson, L.R. 1996. Modelling topographic potential for erosion and deposition using GIS. International Journal of GIS, 10 (5), 629-641.

19. Mitášová, H., Brown, W.M., Johnston, D., Mitáš, L., 1996. GIS tools for erosion/deposition modeling and multidimensional visualization. Part II: unit stream power-based erosion/deposition modeling and enhanced dynamic visualization. Report for USA CERL. University of Illinois, Urbana-Champaign, IL, p. 38.

20. Onyando, J., Kisoyan, P., Chemelil, M.C. 2005, Estimation of Potential Soil Erosion for River Perkerra Catchment in Kenya. Water Resources Management, 19 (2), 133-143.

21. Podhrázská, J., Kučera, J., Karásek, P., Konečná, J. 2015. Land degradation by erosion and its economic consequences for the region of South Moravia (Czech Republic). Soil and Water Research, 10 (2), 105-113.

22. Podhrázská, J., Szturc, J., Karásek, P., Kučera J., Konečná, J. 2019. Economic impacts of farmland degradation in the Czech Republic - Case Study. Agricultural Economics, 60 (11), 529-538.

23. Thomas, J. 2006. Property rights, land fragmentation and the emerging structure of agriculture in Central and Eastern European countries. Journal of Agricultural and Development Economics, 3(2), 225-275.

24. Van Oost, K., Govers, G., 2000. Usle2D: Online manual [online]. Katholieke Universiteit Leuven: 2000, URL:http:/www.kuleuven.be/geography/frg/ modelling/erosion/usle2dhome/

25. Vopravil, J. et al. 2011. Assessment of Land Erodability Factor in the Czech Republic. Water Management, 6, 249-255. (in Czech).

26. Walling E.D. 2009. The impact of global change on erosion and sediment transport by rivers: current progress and future challenges. Paris: UNESCO. Available at http://unesdoc.unesco.org/ images/0018/001850/185078E.pdf.

27. Wischmeier, W.H., Smith, D.D. 1978. Predicting Rainfall Erosion Losses. A Guide to Conservation Planning. The USDA Agricultural Handbook No. 537, Maryland.

28. Zdražil, K. 1965. Economic evaluation of anti-erosive protection. Institute of Scientific and Technical Information of the Ministry of Agriculture, Forestry and Water management of CSSR, Prague. (in Czech). 